\title{
Central Midwest States
}

National Cancer Institute

\section{Source}

National Cancer Institute. Central Midwest States. NCI Thesaurus. Code C43453.

The area in the United States comprised of the following states: Illinois, Missouri, Kansas and Nebraska. 